ідеологічне русло, регламентувати найрізноманітніші прояви творчої активності та інтелектуального пошуку. Втручання режиму вело до деформації творчості митця, література і мистецтво були найважливішими i найдієвишими каналами формування культу особи Й. Сталіна. Однак і в такому важкому стані, попри всі труднощі, «проробки» і гоніння, митцям вдалось зберегти своє творче обличчя, створити цікаві самобутні твори, які стали відомими далеко за межами республіки.

\title{
Література:
}

1. Баран В.К. Україна: новітня історія (1945-1991 р.р.). - Львів, 2003. $-670 \mathrm{c}$.

2. Енциклопедія українознавства: Загальна частина. Т. 2 / Ред. В. Кубійович, З. Кузеля (репринтне відтворення). - Київ, 1994. - 800 с.

3. Замлинська О. Ідеологічний терор та репресії проти творчої інтелігенції у перші повоєнні роки (1945-1947рр.). // Київська старовина. - 1993. - № 2. - С. 73-80.

4. Сірук Н.М. «Ждановщина» в Україні (друга половина 40-х початок 50-х років XX ст.): монографія / Н. М. Сірук. - Луцьк, 2013. $206 \mathrm{c}$.

DOI https://doi.org/10.30525/978-9934-26-004-9-33

\section{«БУДИНОК «СЛОВО»: ДОКУМЕНТАЛЬНА ХРОНІКА РОЗКВІТУ ТА ТРАГЕДІЇ МОДЕРНОЇ УКРАЇНСЬКОЇ КУЛЬТУРИ}

\section{Томенко О. М.}

кандидат філологічних наук, доцент кафедри культури та соціально-гуманітарних дисциплін Національної академії образотворчого мистецттва і архітектури м. Київ, Україна

Дослідження доби «Розстріляного Відродження» - потужного українського мистецького руху - розпочалося ще в 1990-х роках минулого століття. Одним із перших почав вивчати твори та архіви (українські та закордонні) академік Микола Жулинський [2]. За цей час було захищено багато дисертацій, видано твори та монографії, присвячені представникам «Розстріляного Відродження», їхні імена внесені до шкільної програми. Але лише у 2017 році вийшов на екрани 
документальний фільм «Будинок «Слово» режисера Тараса Томенка, який абсолютно по-новому розкрив епоху $20-\mathrm{x}-30$-х років XX століття та «оживив» культурну еліту, що почала творити модерну українську культуру.

За словами літературознавця Дмитра Дроздовського, «Будинок «Слово» - «це художня ревізія одного 3 найцікавіших періодів української культури, пов'язаного з ії найвищим злетом у плані художності. В.Підмогильний, М.Куліш, Микола Хвильовий, П. Тичина, Михайль Семенко, Майк Йогансен ... - у 1920-ті й почасти 1930-ті роки створили потужну модерну українську культуру, орієнтовану на урбаністичну тематику. У цій культурі втілено нову форму світогляду, нову філософію життя, дистанційованого від села [1].

Для більшості 3 нас письменники, художники, режисери «розстріляного відродження» постають як окремі особистості, які творили самі по собі, принаймні, шкільна програма саме так формує бачення цього періоду розквіту української літератури і мистецтва. Ще навчаюсь в університеті, на філологічному факультеті, Тарас Томенко зацікавився цим періодом української історії. I коли він зрозумів, що всі ці геніальні митці і творці жили під одним дахом і щодень спілкувалися, а потім практично всі були репресовані - в нього волосся стало дибки.

Фільм побудований виключно на хронікальних кадрах того часу. Режисерові довелося передивитися десяток кілометрів кінохронік того часу, аби відшукати матеріали для фільму. Перечитати сотні архівних листів разом зі сценаристом Любов'ю Якимчук, перегорнути сотні справ, наклепів і доносів НКВД. Зокрема в архівах Інституту літератури ім. Тараса Шевченка НАН України, Національного музею літератури, архівах СБУ. Деякі з матеріалів були розсекречені нещодавно. Більшість документів була знищена режимом. Факт, що фотографій М.Хвильового залишилося лише 5.

Проте майстерність кінорежисера полягає в тому, що фільм не сприймається, як документальний. Завдяки творчому задуму, талановитому озвученню акторів Ганни Левченко, Бориса Георгієвського та композитору Аллі Загайкевич складається враження, що ти дивишся ігрове кіно, де всі знані митці, наче живі, говорять 3 тобою з екрана, в тому числі і мовою своїх творів, а також живими голосами, які збереглися у фондах радіо. Розкриваються характери мешканців будинку, їхні родинні стосунки, пристрасті, манера вдягатися, творити, їхні достоїнства та вади. Бо перед нами - насамперед живі люди. Ті люди, які були на вістрі новітніх художніх віянь, вони були в авангарді українського мистецтва, вони переламали хід культурного розвитку, вони були кожен по-своєму новаторами в тій царині, де творили. Микола Хвильовий, Остап Вишня, Василь Вражливий, Іван Багряний, Іван 130 
Дніпровський, Олесь Досвітній, Григорій Епік, Наталя Забіла, Майк Йогансен, Антін Крушельницький, Іван Кулик, Микола Куліш, Лесь Курбас, Аркадій Любченко, Іван Маловічко, Вадим Меллер, Анатоль Петрицький, Марія Пилинська, Сергій Пилипенко, Валер'ян Підмогильний, Валер'ян Поліщук, Михайль Семенко, Олекса Слісаренко, Юрій Смолич, Володимир Сосюра, Павло Тичина, Наталя Ужвій, Валентина Чистякова, Михайло Яловий, Юрій Яновський , Іван Падалка, Микола Трублаїні, Василь Седляр, Вадим Меллер...

Недарма до тодішньої столиці України - Харкова з'їхалися на конференцію пролетарських письменників Бертольд Брехт, Теодор Драйзер, Анрі Барбюс. Всі вони побували у будинку «Слово».

Така концентрація талантів на метр квадратний сприяла творчому процесу. Згодом цей будинок-рай перетворився на будинок-пекло, 3 якого щоночі чорний воронок забирав одного з мистців, які вже мали напоготові чемодани 3 речами, спали одягненими, прислухаючись до шороху за дверима.

У цьому харківському будинку 66 квартир, у кожну з яких намагалася заглянути камера режисера і оповісти долю кожного мистця, вихопити момент, відкрити частину тогочасного життя.

Нащадок одного із мешканців (Ігоря Муратова), вже сивий чоловік, який був на київській прем'єрі, вражено зізнався, наскільки точно відтворена атмосфера, навіть голоси і манера спілкування мистців повернули його в дитинство, до тих коридорів і помешкань, де вирувало тогочасне мистецьке життя. На жаль, більшість із сучасних мешканців навіть не уявляє, в чиїх квартирах вона живе і яка національна історія та культура тут творилася.

Так планомірно знищувалася історична пам'ять, яку фільм «Будинок «Слово» не просто відновлює, персоналізує та візуалізує, а й дає можливість осягнути уроки минулого, щоб вони не повторилися в майбутньому.

\section{Література:}

1. Дроздовський Д. Будинок «Слово»: історія трагічного життєлюбства // https://zn.ua/ukr/ART/budinok-slovo-istoriya-tragichnogozhittyelyubstva-260555_.html

2. Жулинський М.Г. Із забуття - в безсмертя : (сторінки призабутої спадщини). К.: Дніпро, 1990. 446 с. 